\title{
Climate Change Knowledge and Awareness Creation in Relation to the Media among Senior High Students in Birim Central Municipal, Ghana.
}

\author{
Emmanuel Awusi ${ }^{1}$, Kofi Asare ${ }^{2}$ \\ ${ }^{1}$ Department of Environmental Science, Garden City University College, Kumasi, Ghana \\ ${ }^{2}$ Business School, GIMPA, Accra, Ghana
}

\begin{abstract}
Climate change has become one of the major Environmental problems facing the world today and the media has been central in making public the distressing evidence of a wide range of its implications on Agriculture, Ecosystems and health. Climate change knowledge and awareness creation are essential for successful adaptation and mitigation. The present study was conducted in the Birim Central Municipal, Ghana, and 400 Senior High Students were randomly selected from five schools. Both closed and open-ended questionnaire was used to assess students' knowledge on climate and their participation in climate change awareness creation.The results revealed that, despite the flourishing media environment Senior High Students in Birim Central Municipal have low climate change knowledge level. Also, there was no statistically significant difference in the level of climate change knowledge with respect to gender, age and the main source of information about climate change. Again, it was found that Senior High School students' involvement in climate change awareness creation is low, and there is a positive relationship between students knowledge level and awareness creation. Implications of the findings on educational curricula, policies and research have been discussed.
\end{abstract}

Keywords: Awareness creation, Climate change, knowledge

\section{Introduction}

Climate change is one of the greatest challenges for humanity and the environment (Harbinson et al., 2006), and it is one of the key challenges to the development of the world (UNDP, 2007). There is the evidence that, rapid climate changes are taking place due to human activities (IPCC, 2001). Although, there are natural causes of climate change, it is largely caused by anthropogenic activities such as the combustion of fossil fuel, industrial pollution, deforestation and land use changes (IPCC, 2007; Weart, 2010). The combustion of fuel and industrial pollution increase the concentration of green house gas in the atmosphere (Canadel, et al., 2010), whiles deforestation and land use change interfere with the absorption of carbon by terrestrial sinks (IPCC, 2007) leading to global warming.

Climate change is of variety of effects, such as rising sea level, desertification, extinction of plant and animal species, shifting of agriculture patterns, and changes in the occurrence of extreme weather (IPCC, 2001; Pitpitunge, 2013). The effect of climate change on crop farming may be different from animal production (Masese et al., 2016) such that it may be favorable to one but unfavorable to the other (IPCC, 2007). The change in rainfall pattern had led to a reduction in soil moisture and hence, a disruption of Agricultural sector. Thus, climate change becomes a concern of international organizations and governmental institutions because of its impacts on different sectors such as agriculture, ecosystem and biodiversity (IPCC, 2007). Climate change has resulted in cases of environmental catastrophes in Africa (Ofei-Nkansah, 2013; The World Bank Group, 2013), and Ghana has not been left out of these (Badu-Agyei, 2012; Boadi, 2013; Kunateh, 2013). Global climate change is therefore a topic of major public interest, not only because its impacts will impinge on many areas of our lives but also because a range of options is available to tackle the causes of the problem.

The $21^{\text {st }}$ century is characterized by a high level of scientific and technical complexities of environmental issues such as climate change (Spellman, 2003). Thus, there is the need for a reasonable level of public scientific literacy as a necessity (Sjoberg, 1997), and this will make the general public good citizens who are in the position to make informed and more accurate decision about scientific issues (Kolstoe, 2000). Education is one of the recommended methods to find solution to the climate change menace (Anderson, 2010; Cherry, 2011; Sharma, 2012). Climate change education, including climate change science and knowledge is one of the climate change initiatives (UNESCO, 2010). Also, Science education on climate change contributes to students' knowledge and competence to adapt and respond to the problem (UNESCO, 2010). Students play important roles in the education on climate change by explaining complex scientific issues to the citizens of their community, and this will partly depend on their Knowledge on climate change Also, students' involvement in environmental education leads to awareness creation for an individual to understand himself and his 
immediate environment (Ali, 2015). Accordingly, science is taught at all levels of education in Ghana except at the pre-school to equip the students solve environmental problems (Boakye, 2014). Thus climate change education leads to awareness creation, and total behavioural and attitudinal change towards sustainable development (Ochieng, 2013)

Public knowledge on climate change has been studied by a lot of researchers (Berk and Schulman, 1995; Fortner et al.,2000; Acquah, 2011; Adebayo et al., 2013) However, most studies on climate change knowledge have focused on specific groups of the population such as tertiary students (Oruonye, 2011;Olajide et al., 2011; Spellman, 2013 ; Gameda \& Akalu, 2015). Other studies also targeted at pre- tertiary students (Boyes and Stanistreet, 1997 ; Owolabi, et al., 2012), and concentrated on conception and perception of climate change. A search through the literature indicates that very little has been done to investigate the level of Senior High students' knowledge on climate change and students participation in climate change awareness creation. Using the Birim Central Municipality in the Eastern Region of Ghana as a reference point, this present study was therefore carried out to help address this lacuna. The main aim was to assess the level of knowledge of Senior High Students on climate change and students participation in public climate change education or awareness creation. Three hypotheses that were tested in the study were: that the level of knowledge of Senior High Students on climate change is high; that gender, age and sources of information on climate change have any link with knowledge about climate change; and that there is correlation between student's climate change knowledge and public awareness creation. The outcome, the authors believe, would go a long way in helping policy makers and stakeholders in the educational sector to identify the shortfalls in climate change science education and subsequently incorporate them in their curriculum. The findings may also be useful to appropriate authorities attempting to initiate the campaign for climate change awareness creation.

\section{Methodology}

This present study was carried out in the Birim Central Municipal, located within the Eastern Region of Ghana, with Akyem Oda as its capital. It lies between latitudes $05^{\circ} 55^{\prime} 29.89^{\prime \prime} \mathrm{N}$ and longitude $00^{\circ} 58^{\prime}$ '55.78', $\mathrm{W}$ of Ghana (fig 1.) It has a total land area of $1,090 \mathrm{Km}^{2}$. The municipality is characterized by a monthly mean temperature around $26{ }^{\circ} \mathrm{C}$, and ranges between $21{ }^{\circ} \mathrm{C}$ and $35{ }^{\circ} \mathrm{C}$. It experiences two rainfall seasons annually. The major season starts in April and ends in July, whiles the minor season begins in September and ends in early November. The Municipal is made up of both urban and peri- urban settlements with a population of 144,869 representing about six percent of the Eastern region's total population (Ghana Statistical Service,2014). It has five Government Senior high schools.

The survey was conducted in February 2016, and a total of 400 randomly selected respondents, (students) from five senior high schools in the Birim Central Municipality were used for this survey. The study evaluated students' general knowledge on climate change, and their participation in climate change awareness creation. A semi- structured questionnaire was used this study, and the reliability of the of the questionnaires was assessed by pretesting 100 questionnaires in one of the schools with similar characteristics as those in the target study area. The scale consists of 50 climate change related statements which were adapted from both the Junior High School and Senior High School Integrated Science text books,( Entsua-Mensah etal.,2009; Kom-Zuta, 2012a; Kom-Zuta 2012b; Kom-Zuta, 2012c ). For each statement, respondents were asked to indicate whether the statement was 'true', 'false' or 'did not know'. These answers represent the three states 'informed', 'misinformed' and 'uninformed'. Correct scores were given +1 , incorrect scores - 1 and 'did not know' was given ' 0 '. A summative approach was used to find the total round score. Respondents were asked to indicate their main source of any information they have on climate change, and were also asked to state, whether or not they have participated in climate change awareness creation. Personal details such as age, sex, and year in Senior High School were obtained from students. Data collected was analyzed using the Statistical Package for Social Sciences (SPSS). 


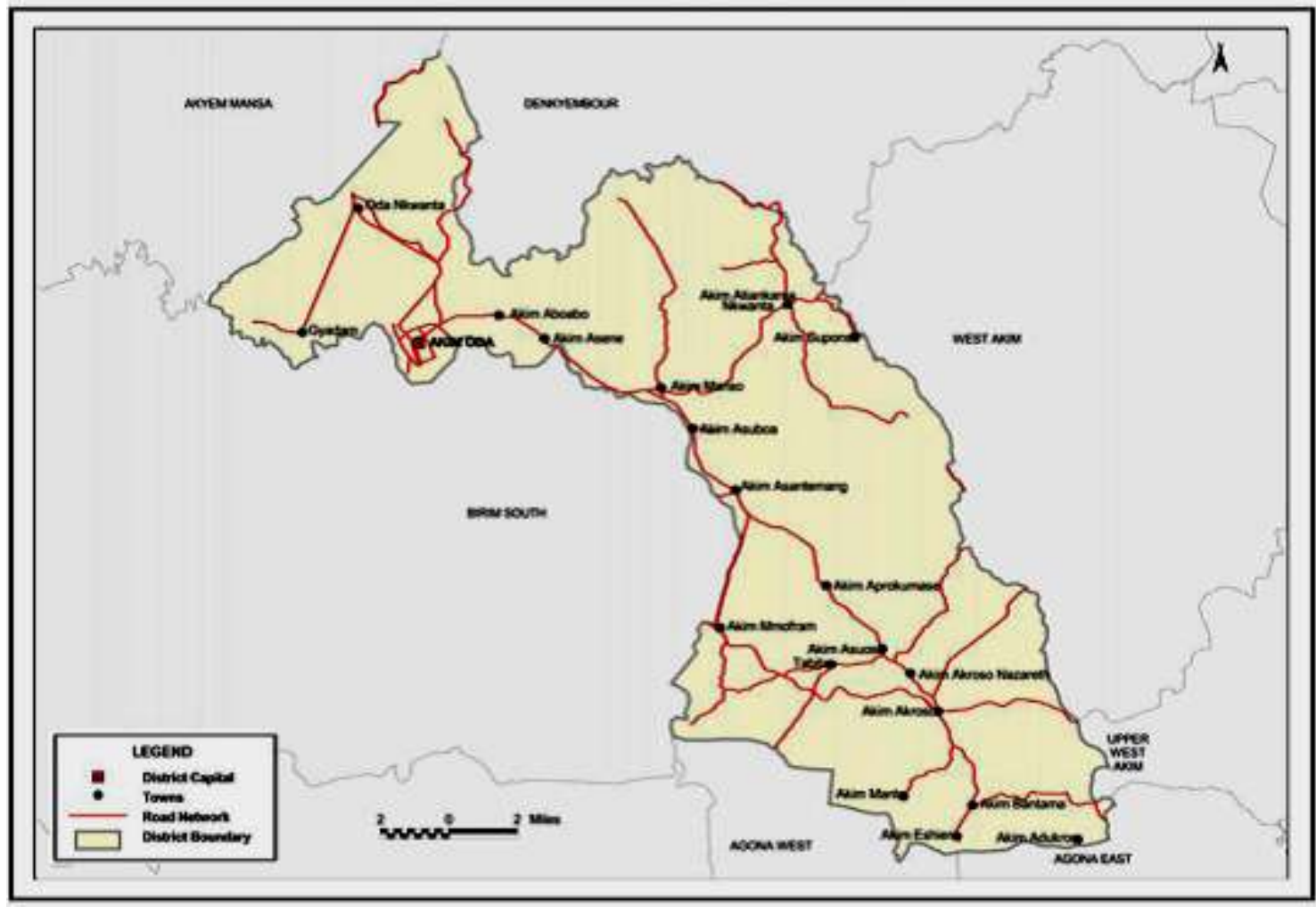

Figure 1: District map of Birim Central Municipal (Source: Ghana Statistical Service)

\section{Results and Discussion}

In this study, 205(51\%) of the respondents were males whereas $195(49 \%)$ were females (Table 1) and Fig 2 below), indicating almost an equal proportion of male and female enrollment in Senior High Schools in Ghana (MOE, 2014). The gender of the respondents was consistent with that of Sah et., al (2015) in a study on climate change in India where $54.5 \%$ were male students, and $45.5 \%$ were female students. Other study by Tse $\mathrm{Ka}$ Ho (2013) in Hong Kong also had similar gender proportion of 56\% male students and $44 \%$ female students. Previously, most Ghanaian parents were not interested in the girl child education for the fear of the girl dropping out of school. However, with the formation of Girl education Unit (GEU) in 1997, the gender gap in enrollment has decreased (Lambert et al., 2012). The inception of the GEU has worked to create female scholarship for promising students, revise text books to make it gender-sensitive, and train women in income generating activities (Lambert et al., 2012)

Table 1: The distribution of gender, age range and the level/year in SHS of respondents $(n=400)$

\begin{tabular}{|c|c|c|c|}
\hline \multicolumn{2}{|l|}{ Characteristics/Profile } & Frequency & Percentage $(\%)$ \\
\hline \multirow[b]{2}{*}{ Gender } & Male & 205 & 51 \\
\hline & Female & 195 & 49 \\
\hline \multirow{3}{*}{ Age range } & $12-15$ years & 58 & 14 \\
\hline & $16-18$ years & 280 & 70 \\
\hline & 19 and above & 62 & 16 \\
\hline \multirow{3}{*}{$\begin{array}{l}\text { Year or level in } \\
\text { SHS }\end{array}$} & $1^{\mathrm{st}}$ & 158 & 40 \\
\hline & $2^{\text {nd }}$ & 124 & 31 \\
\hline & $3^{\text {rd }}$ & 118 & 30 \\
\hline
\end{tabular}

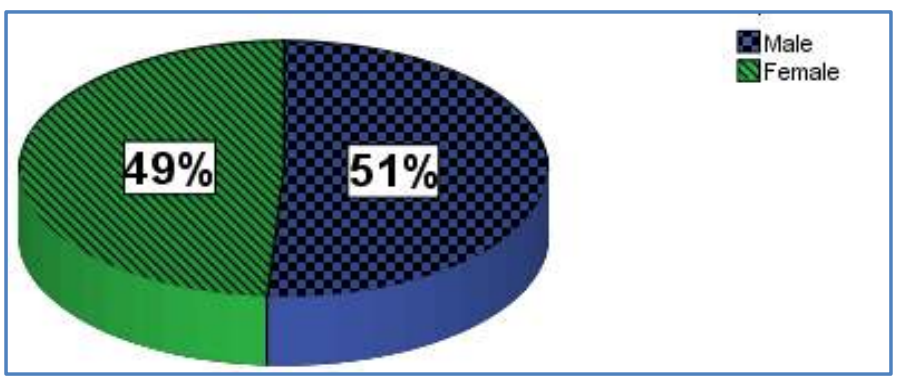

Figure 2: Gender of respondents 
In our study, $58(14 \%)$ of respondents were found in the age category $12-15$ years, $280(70 \%)$ in the 16 18 years category, and $62(16 \%)$ were 19 years and above (Table 1). The highest proportion (70\%) of respondents in the 16-18 years category was anticipated because, this is the age at which majority of students in Ghana are in the Senior High School. Most Ghanaian students enter the Senior High Schools by age 16 years where they spend three years up to age 19 years, with the first 11 years of their education(Age 5-15) being free and compulsory Basic Education (GES, 2014). The age bracket of the majority of the respondents is similar to that of Carr (2015) on climate change study in a Dar es Salaam, where majority(74\%) of surveyed students were between the ages of 14 and 17.

Secondary school students obtain information on climate change from a broad range of sources (Carr, 2015). According to the respondents in the Birim Central Municipality, their main sources of climate change information were the electronic media, 168 (42\%), the print media, 96(24\%), and others like text books and teachers, 136 (34\%) (Table 2 and Fig. 3 below).These results broadly reflect the findings of Olayinka et al., (2013) on study in Nigeria, where the print media and electronic media are the most dominant ways of receiving information on climate change. Nigatu et al., (2014) also had similar results where, most (63.1\%) of the study participants identified electronic mass media (TV and radio) as their most common source of information about climate change. The major source of information on climate change being the electronic media in this study would probably imply that, the integration of climate change topics in different subjects is still inadequate (Calvo and Apilado,2015). Although the electronic media served as the major source of information on climate change in this study, the level of discussion on climate change on radio and television is low, and this limits the amount of information relayed to the public (Twum -Barimah et al., 2015).

Table 2: The distribution of main source of information on climate change and respondents participation in climate change awareness creation.

\begin{tabular}{|l|l|l|l|}
\hline \multicolumn{2}{|c|}{} & Frequency & Percentage (\%) \\
\hline Main source of information on climate change $\mathrm{n}=400$ & Print media & 96 & 24 \\
\cline { 2 - 4 } & Electronic media & 168 & 42 \\
\cline { 2 - 4 } & Others & 136 & 34 \\
\hline $\begin{array}{l}\text { Participation in climate change awareness creation } \\
\mathrm{n}=400\end{array}$ & Yes & 124 & 31 \\
\cline { 2 - 4 } $\begin{array}{l}\text { Method used in the climate change awareness creation } \\
\mathrm{n}=124\end{array}$ & No & 276 & 69 \\
\cline { 2 - 4 } & Posters & 25 & 20 \\
\cline { 2 - 4 } & Banners & 9 & 7 \\
\cline { 2 - 4 } & Videos & 35 & 28 \\
\cline { 2 - 4 } & Petition & 5 & 4 \\
\cline { 2 - 4 } & Drama & 36 & 29 \\
\cline { 2 - 4 } & Others & 15 & 12 \\
\hline
\end{tabular}

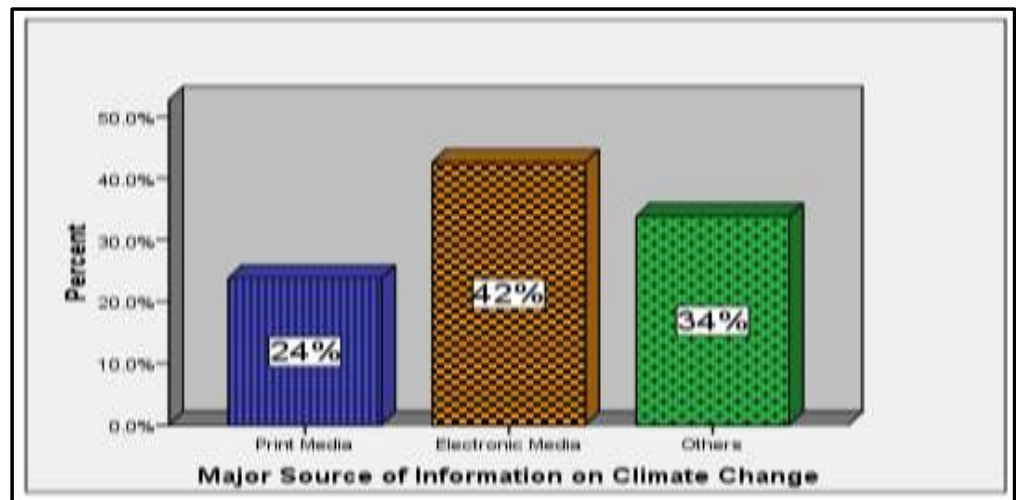

Figure 3: A bar chart showing the major sources of information on climate change

In this study, student's knowledge about climate change was at a low level. On the scale of 50, the minimum score for the climate change knowledge was -17 and the maximum was 36 with a mean of 13.65. Our results is similar to that of Gichuki (2014) in which majority of students had low level of climate change knowledge. A possible reason for the low climate change knowledge in the current study could probably be the poor integration of climate change topics into the curriculum of pre-tertiary education in Ghana, with no climate change topic in the curricula of the lower primary, Grades 1 to 3, and upper primary, Grades 4 to 6 but a small in the curricula of both Junior High and Senior High Schools (Boakye, 2015).

Similar to the findings of (Essouradjane and Raju, 2014), there was no significant difference in the level of knowledge of student with respect to their gender at $p>0.05$. This was obvious because of the stereotypical relationship between women and science (Spellman et al.,2003). There was also no significant difference in the level of climate change knowledge with respect the age of respondents and their sources of 
information about climate change at $p>0.05$.The non-significant difference in the level of climate change knowledge across the age categories is probably because science is taught at all levels of education in Ghana, except at the pre-school to equip the students to solve environmental problems (Boakye, 2015). However, Gichuki (2014) found a significant association between media with climate change knowledge categories, and Cabecinhas (2006) also found similar results. Morgan and Moran (1995) and Wilson and Henson (1993) also found that students who used print media rather than television as their main source of information were more likely to understand the fundamentals issues on climate change.

In our study, 276(69\%) of the respondents have never participated in any climate awareness creation, whereas $124(31 \%)$ have at least once been involved in such an exercise using methods such as Posters, Banners, Videos, Petition, Drama, and others like symposium, forum etc. (Table 2 above and Fig 4 below). This low proportion of respondents' involvement in climate change awareness creation is not surprising because of the non existence or inactivity of Environmental Clubs in most of the various schools sampled or the communities where most of the respondents come from. Helferty and Clarke (2009) found that some students groups in Quebec, Cannada held Environmental awareness week in 2007/2008, which encompassed climate change awareness raising through similar methods such as posters, petitions, film screening, banners and variety of other initiatives

From our results, there was a weak positive correlation between students' knowledge about climate change and climate change awareness creation, which is significant, $r=0.101$ at $p<0.05$, implying that, a significant positive relationship exist between students knowledge about climate change and public awareness creation. Environmental public awareness comes from the result of general knowledge of the Environment, and thus, the role of Students knowledge about climate change in public awareness creation is very important because, there is a need to interpret science in terms of the needs of the general public (Jenkins, 1999)

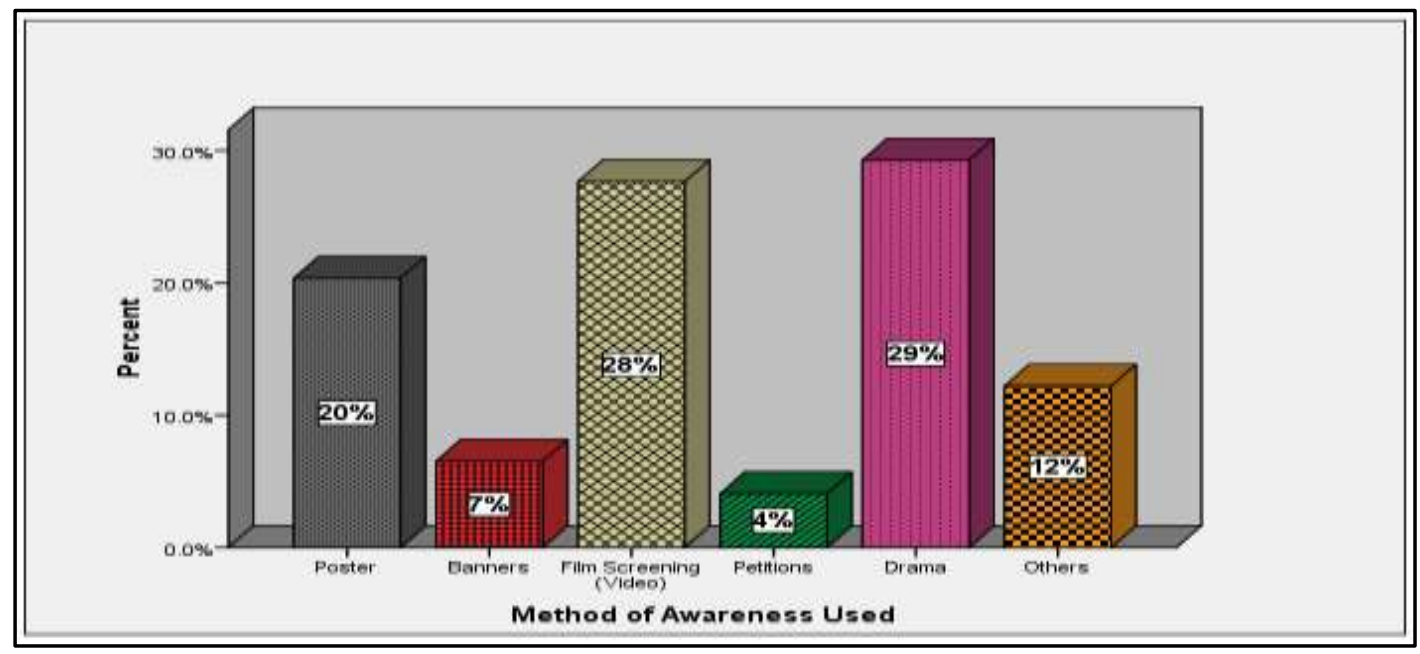

Figure 4: A bar chart showing the methods used for climate change awareness creation.

\section{Conclusions and Recommendation}

This study intended to add to earlier studies advocating for proper integration of climate change issues into education curricula of all pre-tertiary levels in Ghana. Adopting both qualitative and quantitative methods of analysis, we investigated the level of knowledge of Senior High Students on climate change and students participation in public climate change education or awareness creation. As has already been established in the existing literature (Boakye 2015 and Choi et al., 2010), and also confirmed in this current study, there is inadequate information on climate change incorporated in the curricula materials particularly textbooks. Consequently, most $(68 \%)$ of the respondents interviewed pointed to the print and the electronic media as their primary sources of information on climate change issues. However, general knowledge about climate change, especially non-action oriented one, does not directly influence individuals to act towards it.

From our study, we concluded that Senior High Students in the Birim Central Municipal of Ghana have a low level of knowledge about climate change, and there is no statistically significant difference in the level of climate change knowledge between male and female students. There is also no significant difference in the level of climate change knowledge with respect to the age of respondents and their sources of information about climate change. Senior High Students participation in climate change awareness creation is low and there is a positive relationship between students' low knowledge about climate change and public awareness creation. There is therefore the need for action-oriented activities such as the formation of more Environmental Clubs in all Senior High Schools in Ghana to initiate climate change awareness creation. 
The implications for policy makers and Educationists particularly those who are actively involved in drawing the curricula are enormous. They should take some of these calls seriously to ensure an adequate integration of climate change topics into the school curricula at all pre-tertiary levels. The teaching and learning methods should touch 'the heart as well as the mind' of the students . Framing of climate change concepts then becomes vital in writing the education curricula. The point made by George Lakoff in relation to framing is worth revisiting here:

But in reality, environmental frames are the (typically unconscious) conceptual structures that people have in their brain circuitry to understand environmental issues. To understand "the real crises" one needs the right conceptual structures in one's brain circuitry. Frames are communicated via language and visual imagery. The right language is absolutely necessary for communicating "the real crisis." $(2010,74)$.

More studies will however be required on climate change in relation to its successful incorporation into Ghana's educational curricula particularly the pre-tertiary in order for right framing to be adopted.

\section{References}

[1] Harbinson, R., Mugara R., and Chawla, A. (2006). Whatever the Weather: Media Attitudes to Reporting Climate Change. London: Panos Institute Report.

[2] UNDP. (2007). Fighting climate change : Human solidarity in a divided world. New York: UNDP

[3] IPCC (2001) Climate change 2001: Technical summary. http://www.ipcc.ch

[4] IPCC (2007). Climate Change 2007. Synthesis Report. Contribution of Working Groups I, II and III to the Fourth Assessment Report of the Intergovernmental Panel on Climate Change (IPCC). Geneva, Switzerland: IPCC.

[5] Weart, S.R. (2010). The idea of anthropogenic global climate change in the 20th Century. WIREs Climate Change, 1, 67-81.

[6] Masese, O.C., Nyabuti, O.K. and Momanyi, M.J.(2016).Identification of the Weather Shocks Associated With Rainfall in Kisii Central Sub County, Kisii County, Kenya IOSR Journal of Environmental Science, Toxicology and Food Technology, 10 (7), 25 32

[7] IPCC (2007). Climate Change 2007. Synthesis Report. Contribution of Working Groups I, II and III to the Fourth Assessment Report of the Intergovernmental Panel on Climate Change (IPCC). Geneva, Switzerland: IPCC.

[8] Pitpitunge, A. D. (2013). Students Perceptions about Climate change. Asian Journal of Biology Education. 7,1-10

[9] Ofei-Nkansah, K. (2013). Promoting rights in the fight against climate change. Retrieved from http://library.fes.de/pdffiles/bueros/ghana/10516.pdf,

[10] The World Bank Group. (2013). Combating climate change in Africa. Retrieved from http://web.worldbank.org/WBSITE/EXTERNAL/COUNTRIES/AFRICAEXT/0,,contentMDK:22410211 pagePK:146736 piPK:1 46830 theSitePK:258644,00.html

[11] Badu-Agyei, B.(2012). Climate Change impacts on Ghana, are the politicians interested? Retrieved from http://ghananewsagency.org/features/climate-change-impacts-on-ghana-are-the-politicians-interested\&ndash;52641

[12] Boadi, S.(2013, September 16). Climate change problems to affect Ghana. Daily Guide. Retrieved from http://ghananewsagency.org/features/climate-change-impacts-on-ghana-are-the-politicians-interested\&ndash;52641

[13] Kunateh, M.A.(2013,September 24).Climate change threatens Ghana's food security. The Chronicle.Retrieved from http://thechronicle.com.gh/climate-change-threatens-ghana\%E2\%80\%99s-food-security

[14] Spellman, G., Field, K., and Sinclair J.(2003). Assessing UK higher students awareness of global climate change. Weather, 58, 1-8

[15] Sjoberg, S. (1997). Scientific literacy and school science: Arguments and second thoughts. In E. Kal- lerud, \& S. Sjoberg (Eds.), Science, Technology and citizenship: The public understanding of science and technology in science education and research policy (pp. 9-28). Oslo: Norwegian Institute for Studies in Research and Higher Education.

[16] Kolstoe, S. D. (2000) Consensus projects: teaching science for citizenship. International Journal of Science Education, 22, 645664.

[17] Anderson, A. (2010). Combating climate change through quality education. New York: United States of America Publications

[18] Cherry, L.(2011). Young voices on climate change: The Paul F-Brandwein 2010 NSTA lectures. Journal of Science Education and Technology,20, 208-213.

[19] Sharma, A.(2012). Global climate change: What has science education got to do with it? Science and Education, 21,33-53

[20] United Nations Educational Cultural and Scientific Organization (UNESCO). (2010). The UNESCO climate Change initiative: Climate change education for sustainable development. Retrieved , from 'ttp://unesdoc.unesco.org/images/0019/001901/190101E.pdf

[21] Ali, A. R.(2015). Influence of School Location on Environmental Awareness Level among Secondary School Students in Terengganu, Malaysia. IOSR Journal of Environmental Science, Toxicology and Food Technology, 9 (3), 54-61

[22] Boakye, C.(2015).Climate change education:The Role of Pre-Tertiary Science Curricula in Ghana. SAGE Open,54,1-10.Available at http://sgo.sagepub.com/content/spsgo/5/4/2158244015614611.full.pdf,

[23] Ochieng, M.A .(2014). Climate change awareness and policy implication among primary school teachers in Kisimu City, Kenya, Master's thesis, kenyatta university, Kenya.

[24] Berk, R. A., and Schulman, D. (1995) Public perceptions of global warming. Climate Change, 29,1-33.

[25] Fortner, R. (2001). Climate change in school: where does it fit and how ready are we? Canadian Journal of Environmental Education, 6, 18-31.

[26] Acquah, H.D. (2011). Public awareness and quality of knowledge regarding climate change in Ghana: A logistic regression approach. Journal of Sustainable Development in Africa,13,146-157.

[27] Adebayo, A.A., Mubi, A.M., Zemba, A.A. and Umar, A.S. (2013). Awareness of climate change impacts and adaptation in Adamawa State,Nigeria. International Journal of Environment, Ecology, Family and Urban Studies, 3(1), 11-18.

[28] Oruonye, E.D. (2011). An assessment of the level of awareness of the effects of climate change among students of tertiary institutions in Jalingo Metropolis, Taraba State Nigeria. Journal of Geography and Regional Planning, 4, 513-517.

[29] Olajide, F.O., Owolabi, O.A., Olajide, A.O., Oospore, A.G., Unlade, A.O., and Omobuwa, O. (2011). Knowledge about the causes, consequences And control of climate change among undergraduates of Obafemi Awolowo University, Ile Ife. In Salami A.T. \& Orimoogunje O.O.I (Eds)Environmental research and challenge of sustainable development. Ile Ife: OAU Press.

[30] Gameda, D.O, Akalu, D. S.(2015). Climate Change Adaptation and Mitigation: Students knowledge and Experience in Jimma University,Ethiopia. International Journal of Sciences: Basic and Applied Research (IJSBAR),23(2), 123-137. 
[31] [31] Boyes, E., and Stanisstreet, M. (1997). Children's models of understanding of two major global environmental issues (ozone layer and greenhouse effect). Research in Science \& Technological Education, 15(1): 19-28.

[32] Owolabi, H.O., Gyimah, E.K. and Amponsah, M.O. (2012). Assessment of junior high school students' awareness of climate change and sustainable development in central region, Ghana. Educational Research Journal, 2(9), 308-317.

[33] Ghana Statistical Service, (2014). 2010 Population and Housing Census. District Analytical Report. Birim Central Municipality.

[34] Entsua-Mensah, M., Boateng-Ennimful,E., Darbah V.F. Koomson J.B (2009). Integrated Science for Senior High Schools. Accra, Ghana: Excellent publishing and printing.

[35] Kom-ZutaT. E. T.(2012a). New integrated science for junior high schools (Pupil's Book 1, 3rd ed.). Accra, Ghana: Sedco.

[36] Kom-ZutaT. E. T.(2012b). New integrated science for junior high schools (Pupil's Book 2, 3rd ed.). Accra, Ghana: Sedco.

[37] Kom-ZutaT. E. T.(2012c). New integrated science for junior high schools (Pupil's Book 3, 3rd ed.). Accra, Ghana: Sedco.

[38] Ministry of Education (2014). Report on basic Statistics and Planning Parameters for Senior High Schools in Ghana 2013/2014 EMIS Report, June 2014

[39] Sah, J.K.., Asha, A.B. and Mubashir, A. (2015). Assessment of the Knowledge and Attitude Regarding Global Warming among High School Students of Ramnagar, Belagavi city: A Cross-Sectional Study. IOSR Journal of Dental and Medical Sciences (IOSRJDMS), 14 (4), 74-78.

[40] Tse Ka Ho, A. (2013).Students' perceptions on climate change and engagement in low-carbonbehaviours: implications for climate change education in Hong Kong. Master's Thesis, The University of Hong Kong.

[41] Lambert, M., Perrino, E. S., and Barreras, E. M. (2012). Understanding the barriers to female education in Ghana. Retrieved September, 10, 2012.

[42] Ghana Education Service (2014). Basic curriculum Education: The Junior High Education."Retrieved from www.ges.gov.gh/?=content basic-education-curriculum

[43] Carr, P. (2015). Climate change awareness amongst secondary level students' in a Dar es Salaam University College of Education (DUCE) affiliated school in urban Tanzania. Masters' Thesis, Trinit College Dublin/ University College Dublin.

[44] Olayinka C. O., Kolawole C. I., Ayodeji O. O., Lekan M. A., Patience F. T. (2013).Improving Urban Residents' Awareness of the Impact of Household Activities on Climate Change in Lagos State, Nigeria. Journal of Sustainable Development; 6(4). doi:10.5539/jsd.v6n4p56 URL: http://dx.doi.org/10.5539/jsd.v6n4p56

[45] [Nigatu, A. S.,Asamoah B. O., and kloos, H. (2014). Knowledge and perceptions about the health impact of climate change among health Sciences students in Ethiopia: a cross-sectional study BMC PublicHealth. 14, 587, Retrieved from, http://bmcpublichealth.biomedcentral.com/articles/10.1186/14712458-14-587,

[46] Calvo, E. D.and Apilado, M.S. (2015). Awareness, knowledge and attitude on climate change of students:Input for the Development of ICM on Climate Change. International Journal of Current Research, 7 (5), 15857-15859.

[47] Twum- Barimah,P., Osei, K.S., and Oppong, D. (2015): Assessment of people 's Knowledge and Perception on Climate Change: A case study of Asunafo North District, Ghana. International Journal of Innovative Research in Science, Engineering and Technology. 4 (1), 18417-18424.

[48] Gichuki, M. W. (2014). Awareness and sources of climate change information among secondary school students in Nairobi County, Kenya. Master's Thesis, The School of Environmental Studies of Kenyatta University

[49] Essouradjane, I.and Raju, G. (2014).A Study on Higher Secondary Students Knowledge on Climatic Change Knowledge in Relation to Environmental Attitude. International Journal of Interdisciplinary and Multidisciplinary Studies, 1 (3), 80-83.

[50] Cabecinhas, R., Lazaro, A., and Carvalho, A. (2006) Lay Representations on Climate Change. In Proceedings of IAMCR's 25th Conference, Cairo, 24-28 ${ }^{\text {th }}$ July.

[51] Morgan, M. D. and Moran, J. M. (1995) Understanding the greenhouse effect and the ozone shield: An index of scientific literacy among University students. Bull. Am. Meteorol. Soc., 76(7), 1185-1190

[52] Helferty, A., and Clarke, A. (2009). Student-led campus climate change initiatives in Canada, International Journal of Sustainability in Higher Education, 10 (3), 287 - 300

[53] Jenkins, E.W. (1999) (Ed.) Innovations in science and technology education. Volume VI,Unesco, Paris

[54] Choi, S. D., Niyogi, D., Shepardson, D. P. andCharusombat, U. (2010). Do earth and Environmental science textbooks promote middle and high school students' conceptual development about climate change?:Textbooks' consideration of students' misconceptions. Bulletin of the American Meteorological Society .91, 889-898.http://journals.ametsoc.org/doi/pdf/10.1175 /2009BAMS2625.1

[55] Lakoff, G.(2010).Why it Matters How We Frame the Environment, Environmental Communication, 4(1), 70-81. 